\title{
Sphingomonas cloacae sp. nov., a nonylphenol- degrading bacterium isolated from wastewater of a sewage-treatment plant in Tokyo
}

\author{
Katsuhiko Fujii, ${ }^{1}$ Naoto Urano, ${ }^{1}$ Hideki Ushio, ${ }^{1}$ Masataka Satomi ${ }^{2}$ \\ and Shigeru Kimura ${ }^{1}$
}

Author for correspondence: Naoto Urano. Tel: +8135463 0588. Fax: +81354630589.

e-mail: urano@tokyo-u-fish.ac.jp

\footnotetext{
1 Laboratory of Marine Biochemistry, Tokyo University of Fisheries, Konan, Minato, Tokyo 108-8477, Japan

2 Food Processing Division, National Research Institute of Fisheries Science, Fukuura, Kanazawa, Yokohama 236-8648, Japan
}

\begin{abstract}
A nonylphenol-assimilating bacterium isolated at a sewage-treatment plant in Tokyo was studied phenotypically, genotypically and phylogenetically. Analysis of the 165 rDNA sequence, the G+C content of the DNA (63 mol \%) and the isoprenoid quinone composition, as well as the presence of sphingoglycolipid and the whole-cell fatty acid profile, revealed that the isolate is a member of the genus Sphingomonas. However, the sequence similarity of the 16S rDNA with that of known Sphingomonas spp. was found to be at most $96 \%$, implying that the isolate is distinctive. Furthermore, the results of DNA-DNA hybridization experiments and its physiological characteristics clearly indicated that the isolate represents a new Sphingomonas species, for which the name Sphingomonas cloacae is proposed; strain S-3 $^{\mathrm{T}}$ ( = JCM $10874^{\mathrm{T}}=$ IAM $14885^{\mathrm{T}}$ ) is the type strain.
\end{abstract}

Keywords: Sphingomonas cloacae sp. nov., biodegradation, endocrine disrupter chemical, nonylphenol

\section{INTRODUCTION}

Nonylphenol (NP) is known as an important intermediate in the production of many kinds of commercial and industrial materials. Above all, NP is used in the production of nonylphenol polyethoxylate, a nonionic surfactant with many industrial applications. However, NP is also known as a ubiquitous pollutant in urban aquatic environments, with concentrations in the p.p.b. $\left(\mu \mathrm{g}^{-1}\right)$ order, and is found in both sediment and surface water (Giger et al., 1984; Ahel \& Giger, 1985; Brunner et al., 1988; Marcomini et al., 1990; Rudel et al., 1996; Isobe \& Takada, 1998; Kojima \& Watanabe, 1998). There is growing evidence that NP has a certain oestrogenic activity (Granmo et al., 1989; Ekelund et al., 1990; Soto et al., 1991; Ahel et al., 1993; Jobling \& Sumpter, 1993; Gray \& Metcalfe, 1997; Ren et al., 1997; Shurin \& Dodson, 1997; Ashfield et al., 1998; Coldham et al., 1998; Sonnenschein \& Soto, 1998).

Recently, we have found significant NP-degrading activity in wastewater of a sewage-treatment plant in

Abbreviation: NP, nonylphenol.

The GenBank/DDBJ accession number for the 165 rDNA sequence of strain $\mathrm{S}-3^{\top}$ is $\mathrm{AB} 040739$.
Tokyo (Fujii et al., 2000) and have isolated a NPdegrading bacterium (K. Fujii and others, unpublished data), which has been designated strain $\mathrm{S}-3^{\mathrm{T}}$. This strain degraded 1000 p.p.m. NP, i.e. a 100001000000 -fold higher concentration than found in urban environments, almost completely within $10 \mathrm{~d}$. Analysis of 16S rDNA partial sequences strongly suggested that the bacterium is a novel species of the genus Sphingomonas.

To precisely identify and phylogenetically place strain $\mathrm{S}-3^{\mathrm{T}}$, phenotypic characterization, analysis of isoprenoid quinone composition, fatty acid composition, polar lipid pattern and DNA $\mathrm{G}+\mathrm{C}$ content, 16S rDNA sequencing and DNA-DNA hybridization were carried out. On the basis of our results we propose that $\mathrm{S}-3^{\mathrm{T}}$ should be placed in a new species of the genus Sphingomonas, Sphingomonas cloacae.

\section{METHODS}

Chemicals. Yeast nitrogen base without amino acids (YNB), Bacto agar and tryptic soy agar were purchased from Difco. NP was obtained from Kanto Chemical. Nutrient broth and nutrient agar were purchased from Eiken Chemical. Other materials and chemicals used were available from commercial sources. 
Table 1 List of bacterial species analysed in this study

\begin{tabular}{|c|c|c|}
\hline Species & Strain* & 16S rDNA accession no. \\
\hline Sphingomonas cloacae $\dagger$ & $\mathrm{S}-3^{\mathrm{T}}\left(=\mathrm{JCM} 10874^{\mathrm{T}}\right)$ & AB040739 \\
\hline Sphingomonas yanoikuyae & IFO $15102^{\mathrm{T}}\left(=\right.$ JCM $\left.7370^{\mathrm{T}}\right)$ & X85023 \\
\hline Sphingomonas paucimobilis & IFO $13935^{\mathrm{T}}\left(=\right.$ ATTC $\left.29837^{\mathrm{T}}\right)$ & X72722 \\
\hline Sphingomonas chlorophenolica & $\operatorname{JCM} 10275^{\mathrm{T}}\left(=\right.$ ATTC $\left.33790^{\mathrm{T}}\right)$ & X87161 \\
\hline Sphingomonas sp. RA2 & DSM 6824 (= ATTC 39723) & X87162 \\
\hline Sphingomonas herbicidovorans & DSM $11029^{\mathrm{T}}\left(=\mathrm{IFO} 16415^{\mathrm{T}}\right)$ & AB022428 \\
\hline Sphingomonas sp. HV3 & HAMBI 2249 & Y12803 \\
\hline Sphingomonas sanguinis & IFO $13937^{\mathrm{T}}\left(=\right.$ ATCC $\left.51382^{\mathrm{T}}\right)$ & D13726 \\
\hline Sphingomonas natatoria & $\operatorname{DSM} 3183^{\mathrm{T}}\left(=\operatorname{ATCC} 35951^{\mathrm{T}}\right)$ & AB024288 \\
\hline Sphingomonas capsulata & IFO $12533^{\mathrm{T}}\left(=\right.$ ATTC $\left.14666^{\mathrm{T}}\right)$ & D16147 \\
\hline Sphingomonas asaccharolytica & IFO $15499^{\mathrm{T}}\left(=\right.$ ATTC $\left.51839^{\mathrm{T}}\right)$ & Y09639 \\
\hline Sphingomonas trueperi & ATCC $12417^{\mathrm{T}}\left(=\mathrm{DSM} 7225^{\mathrm{T}}\right)$ & X97776 \\
\hline Sphingomonas parapaucimobilis & $\operatorname{JCM} 7510^{\mathrm{T}}\left(=\operatorname{ATCC} 51231^{\mathrm{T}}\right)$ & D13724 \\
\hline Sphingomonas echinoides & $\operatorname{ATCC} 14820^{\mathrm{T}}\left(=\mathrm{DSM} 1805^{\mathrm{T}}\right)$ & AB033944 \\
\hline Sphingomonas pruni & IFO $15498^{\mathrm{T}}\left(=\right.$ ATTC $\left.51838^{\mathrm{T}}\right)$ & Y09637 \\
\hline Sphingomonas mali & IFO $15500^{\mathrm{T}}\left(=\right.$ ATTC $\left.51840^{\mathrm{T}}\right)$ & Y09638 \\
\hline Sphingomonas suberifaciens & $\operatorname{DSM} 7465^{\mathrm{T}}\left(=\operatorname{ATTC} 49355^{\mathrm{T}}\right)$ & D13737 \\
\hline Sphingomonas macrogoltabidus & IFO $15033^{\mathrm{T}}\left(=\right.$ ATTC $\left.51380^{\mathrm{T}}\right)$ & D13723 \\
\hline Sphingomonas terrae & IFO $15098^{\mathrm{T}}\left(=\right.$ ATCC $\left.51381^{\mathrm{T}}\right)$ & D13727 \\
\hline Sphingomonas adhaesiva & $\mathrm{JCM} 15099^{\mathrm{T}}(=$ ATCC 51229 $)$ & X72720 \\
\hline Sphingomonas subarctica & $\mathrm{JCM} 10398^{\mathrm{T}}\left(=\mathrm{DSM} 10700^{\mathrm{T}}\right)$ & X94102 \\
\hline Sphingomonas subterranea & ATCC $700279^{\mathrm{T}}\left(=\right.$ DSM $\left.12447^{\mathrm{T}}\right)$ & AB025014 \\
\hline Sphingomonas aromaticivorans & ATCC $700278^{\mathrm{T}}\left(\mathrm{DSM} 12444^{\mathrm{T}}\right)$ & AB025012 \\
\hline Sphingomonas stygia & ATCC $700280^{\mathrm{T}}\left(\mathrm{DSM} 12445^{\mathrm{T}}\right)$ & AB025013 \\
\hline Sphingomonas xenophaga & DSM $6383^{\mathrm{T}}$ & X94098 \\
\hline Agrobacterium rhizogenes & IFO $13257^{\mathrm{T}}\left(=\right.$ ATTC $\left.11325^{\mathrm{T}}\right)$ & D12788 \\
\hline
\end{tabular}

* IFO, Institute for Fermentation, Osaka, Japan; JCM, Japan Collection of Microorganisms, Saitama, Japan; ATTC, American Type Culture Collection, Manassas, VA, USA; DSM, Deutsche Sammlung von Mikroorganismen und Zellkulturen GmbH, Braunschweig, Germany; HAMBI, Culture Collection of the Department of Microbiology, University of Helsinki, Finland.

$\dagger$ Isolated in this study.

† Sequenced in this study.

Isolation of the NP-degrading bacterium. Strain S-3 ${ }^{\mathrm{T}}$ was isolated from wastewater of a sewage-treatment plant in Tokyo. For isolation of S-3 $3^{\mathrm{T}}$, YNB agar $\left(\mathrm{pH} 7 \cdot 0\right.$ at $\left.25^{\circ} \mathrm{C}\right)$ containing $0 \cdot 1 \%(\mathrm{w} / \mathrm{v})$, i.e. 1000 p.p.m., NP (NP/YNB agar) was used. YNB consists of $\left(\mathrm{NH}_{4}\right)_{2} \mathrm{SO}_{4}$ as the nitrogen source, other salts $\left(\mathrm{KH}_{2} \mathrm{PO}_{4}, \mathrm{MgSO}_{4}, \mathrm{NaCl}\right.$ and $\left.\mathrm{CaCl}_{2}\right)$, trace metals and very small amounts of vitamins, as described in the Difco manual. NP is therefore considered to be nearly the sole carbon source in the NP/YNB medium.

Bacterial strains. The bacterial strains used in this study are listed in Table 1. They were obtained from the Institute for Fermentation (IFO), Osaka, Japan, the Japan Collection of Microorganisms (JCM), Saitama, Japan, Deutsche Sammlung von Mikroorganismen und Zellkulturen $\mathrm{GmbH}$ (DSMZ), Braunschweig, Germany, and the Culture Collection of the Department of Microbiology (HAMBI), University of Helsinki, Finland. Recommended and known growth media were used to grow these organisms. S- $3^{\mathrm{T}}$ has been deposited in JCM as Sphingomonas cloacae JCM $10874^{\mathrm{T}}$.

Morphology. Cell morphology was examined using transmission electron microscopy (model H-7000; Hitachi). In preparation for electron microscopy, bacterial cells were suspended in $500 \mu 10.85 \% \mathrm{NaCl}$. Subsequently, the cells were dried on a carbon-coated mesh, stained with $3 \%$ uranyl acetate and examined.

Physiological and biochemical characterization. Oxygen requirement for growth was tested with nutrient agar and the BBL GasPak Anaerobic System (Becton Dickinson). Oxidase and catalase tests were carried out with the Poremedia Oxidase Test Indicator (Eiken) and 3.0\% hydrogen peroxide, respectively. API50 carbohydrate substrate strips (BioMérieux) were used to determine the assimilation pattern of test organisms. Assimilation of carbohydrates was also examined by aerobic cultivation with YNB $(\mathrm{pH} 7 \cdot 0$ at $25^{\circ} \mathrm{C}$ ) containing $1.0 \%$ carbohydrate to confirm the data obtained with API50. APIZYM (BioMérieux) was used to determine biochemical characteristics.

DNA preparation. Chromosomal DNA was purified by standard procedures (Sambrook et al., 1989) from bacterial cells harvested from nutrient broth after growth for $48 \mathrm{~h}$ at $25^{\circ} \mathrm{C}$. Subsequently, the bacterial cells were suspended in Tris/EDTA buffer (pH 8.0) and lysed with lysozyme (final concentration $2 \mathrm{mg} \mathrm{ml}^{-1}$ ) and SDS (final concentration $0.5 \%$ ). Chromosomal DNA was then recovered from the lysate by phenol/chloroform extraction, followed by RNase treatment, cetyltrimethylammonium bromide (CTAB) treat- 
ment and ethanol precipitation. We performed each procedure twice to obtain highly pure DNA.

DNA base composition and DNA-DNA hybridization. The DNA base composition, i.e. the $\mathrm{G}+\mathrm{C}$ content, was determined by a HPLC method, as described by Tamaoka \& Komagata (1984). Sphingomonas chlorophenolica was used as control.

DNA-DNA hybridization experiments were carried out by microplate hybridization methods (Ezaki et al., 1989) using photobiotin labelling and colorimetric detection (Satomi et al., 1997), with 1,2-phenylenediamine (Sigma) as the substrate and streptavidin-peroxidase conjugate (Boehringer Mannheim) as the colorimetric enzyme. The experiment was independently done three times.

16S rDNA sequencing and phylogenetic analysis. Nearly complete 16S rDNA (1417 bases) was amplified by PCR, using a universal primer set corresponding to positions 8-27 (forward primer) and 1492-1510 (reverse primer) of the Escherichia coli numbering system (Weisburg et al., 1991). The PCR operating conditions were similar to those described by Suzuki \& Yamasato (1994). Direct sequencing of the amplified DNA fragments was carried out as described by Satomi et al. (1997). Similarity of $16 \mathrm{~S}$ rDNA sequences between strain $\mathrm{S}-3^{\mathrm{T}}$ and other species was compared with all known sequence data in the GenBank, EMBL and DDBJ databases using the BLAST algorithm (Altschul et al., 1990). Data analysis was performed with CLUSTAL w software (Thompson et al., 1994) and the PHYLIP program (Felsenstein, 1995). Nucleotide substitution rates $\left(K_{\text {nuc }}\right.$ values) were calculated by the methods of Kimura (1980), and a phylogenetic tree was constructed using the neighbourjoining method of Saitou \& Nei (1987). The sequence accession numbers of bacteria used in the phylogenetic analysis are shown in Table 1.

Fatty acid composition. Whole-cell lipids were extracted according to the methods of Bligh \& Dyer (1959). The extracted lipids were converted to fatty acid methyl esters following the methodology of the American Oil Chemists' Society (1990). Hydroxylated fatty acids were trimethylsilylated prior to $\mathrm{GC} / \mathrm{MS}$ analysis, for which a GC-17A gas chromatograph interfaced with a QP-5000 mass spectrometer (Shimadzu) was used. The experimental conditions used were: OMEGA WAX column $(30 \mathrm{~m} \times 0.25 \mathrm{~mm}$; Supelco); injection volume, $0.8 \mu \mathrm{l}$; carrier gas, helium ( $1 \mathrm{ml}-$ $\min ^{-1}$ ); temperature gradient, $150{ }^{\circ} \mathrm{C}$ for $4 \mathrm{~min}, 150$ to $180{ }^{\circ} \mathrm{C}$ at $5^{\circ} \mathrm{C} \mathrm{min}{ }^{-1}, 180$ to $240{ }^{\circ} \mathrm{C}$ at $2{ }^{\circ} \mathrm{C} \mathrm{min}{ }^{-1}, 240{ }^{\circ} \mathrm{C}$ for $10 \mathrm{~min}$, resulting in a total run time of $50 \mathrm{~min}$. The injection port temperature was $250^{\circ} \mathrm{C}$. The ionization energy and temperature for electron impact ionization were $70 \mathrm{eV}$ and $280^{\circ} \mathrm{C}$, respectively. S. chlorophenolica was used as control. TLC of polar lipids. Polar lipids were extracted from cell membranes by the methods of Bligh \& Dyer (1959), and subsequently analysed by two-dimensional TLC. The crude lipids were separated twice on Silica gel 60 TLC plates $(20 \times 20 \mathrm{~cm}$; Merck) with two solvent systems, one being chloroform/methanol/water $(65: 25: 4$, by vol.) and the other chloroform/methanol/acetic acid/water $(80: 12: 15: 4$, by vol.). A $50 \%$ sulphuric acid solution was used to detect spots of all kinds of lipids. $\alpha$-Naphthol/sulphuric acid, periodate-Schiff reagent, Zinzadze (Dittmer) reagent and ninhydrin were used for the detection of sugars, $\alpha$-glycols, phosphate and free amino groups, respectively. Crude lipids of S. chlorophenolica were used as control.

Isoprenoid quinone composition. The isoprenoid quinone type and isoprenoid length were analysed according to the methods described by Yamada \& Kuraishi (1982). Total acetone-soluble extracts of whole cells were separated by one-dimensional TLC with benzene as the eluent. Isoprenoid length was analysed by HPLC using a reverse-phase column (Cosmosil C-18 Econopak column; Nakarai Tesque). S. chlorophenolica was used as control.

Nucleotide sequence accession number of the new isolate. The 16S rDNA sequence of strain $\mathrm{S}-3^{\mathrm{T}}$ has been deposited in the DDBJ database (DNA Database of Japan, Shizuoka, Japan) under accession number AB040739.

\section{RESULTS AND DISCUSSION}

\section{Morphological characteristics}

Strain $\mathrm{S}-3^{\mathrm{T}}$ was found to be aerobic, Gram-negative and rod-shaped $(2 \cdot 0-3 \cdot 1 \mu \mathrm{m}$ in length and $1 \cdot 1-1 \cdot 4 \mu \mathrm{m}$ in diameter) (Fig. 1). The strain formed creamy white colonies on nutrient agar and tryptic soy agar in 3-4 d at $25^{\circ} \mathrm{C}$. It required about 1 week to form visible colonies on NP/YNB agar at this temperature. This may be explained by the fact that NP/YNB is a minimal salt medium, as described in Methods. Colony growth was not observed at temperatures of 4 or $42{ }^{\circ} \mathrm{C}$.

\section{Physiological and biochemical characteristics}

The characteristics of $\mathrm{S}-3^{\mathrm{T}}$ are summarized in Table 2. $\mathrm{S}-3^{\mathrm{T}}$ did not assimilate any carbohydrates tested in this study. Since other Sphingomonas spp. tested assimilated many different kinds of carbohydrates under the same experimental conditions, the experimental system seemed to work properly. S- $3^{\mathrm{T}}$ was also cultured aerobically in $\mathrm{YNB}\left(\mathrm{pH} 7.0\right.$ at $25^{\circ} \mathrm{C}$ ) containing $1.0 \%$ carbohydrate or NP using a rotary shaker. Again, no carbohydrates were assimilated, whereas NP was utilized for bacterial growth, suggesting that the results obtained from our experiments were reliable. We suspected that the negative results of S- $3^{\mathrm{T}}$ might be due

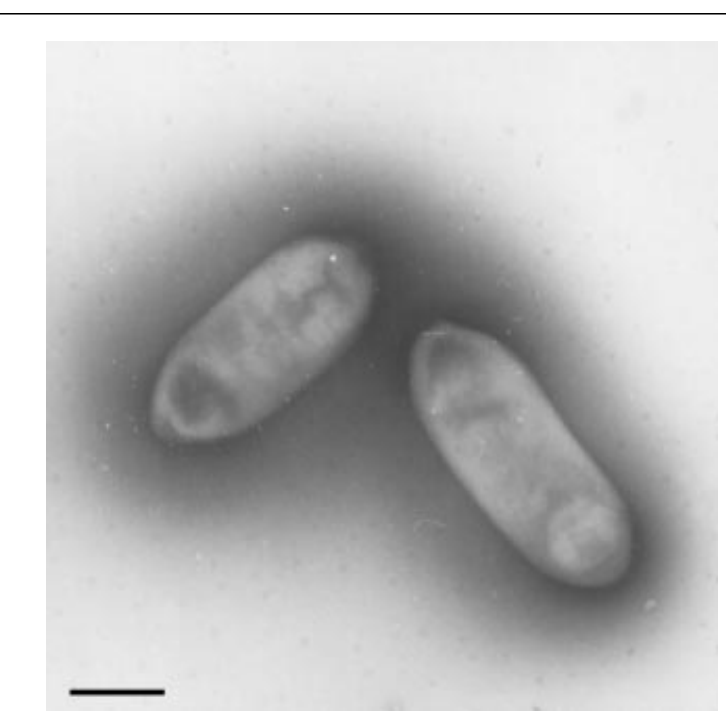

Fig. 1. Transmission electron micrograph of $S-3^{\top}$ cells. Bar, $1 \mu \mathrm{m}$. 
Table 2 Characteristics which differentiate S-3 $3^{\top}$ from other Sphingomonas species

Abbreviations: pau, S. paucimobilis; yan, S. yanoikuyae; chl, S. chlorophenolica; hrb, S. herbicidovorans; RA2, Sphingomonas sp. RA2; HV3, Sphingomonas sp. HV3; sng, S. sanguinis; cps, S. capsulata; nat, S. natatoria; asc, S. asaccharolytica. +, Positive result; - , negative result.

\begin{tabular}{|c|c|c|c|c|c|c|c|c|c|c|c|}
\hline Characteristic & $S-3^{T}$ & pau & yan & chl & $h r b$ & RA2 & HV3 & sng & cps & nat & asc \\
\hline \multicolumn{12}{|l|}{ Assimilation of:* } \\
\hline L-Arabinose & - & + & + & - & - & - & + & + & - & - & - \\
\hline D-Xylose & - & + & + & - & - & - & - & + & + & + & - \\
\hline Galactose & - & + & - & - & + & - & + & + & - & - & - \\
\hline D-Glucose & - & + & + & + & + & + & + & + & + & + & + \\
\hline D-Fructose & - & + & - & - & - & - & + & + & + & - & - \\
\hline D-Mannose & - & + & - & - & - & - & - & + & - & - & + \\
\hline Rhamnose & - & - & + & - & + & - & - & - & - & - & - \\
\hline$N$-Acetylglucosamine & - & + & - & - & - & - & - & + & - & - & + \\
\hline Arbutin & - & + & - & - & - & - & - & + & - & - & - \\
\hline Salicin & - & + & - & - & - & - & - & + & - & + & - \\
\hline Cellobiose & - & + & + & + & - & - & - & + & + & - & - \\
\hline$\beta$-Gentiobiose & - & + & - & + & - & - & - & + & - & - & - \\
\hline Amidon & - & + & + & - & - & - & - & + & - & - & - \\
\hline Amygdalin & - & + & - & - & - & - & - & + & + & - & - \\
\hline D-Raffinose & - & + & + & - & - & - & - & + & - & - & - \\
\hline Melezitose & - & + & - & - & - & - & - & + & + & - & - \\
\hline Lactose & - & + & + & - & - & - & - & + & + & - & + \\
\hline Maltose & - & + & + & - & - & - & + & + & + & + & + \\
\hline Melibiose & - & + & + & - & - & - & - & + & - & - & + \\
\hline Sucrose & - & + & + & - & - & - & - & + & + & + & - \\
\hline Trehalose & - & + & - & - & - & - & - & + & + & - & - \\
\hline D-Fucose & - & + & + & - & - & - & + & - & + & - & - \\
\hline L-Fucose & - & - & - & - & + & - & - & + & - & - & - \\
\hline D-Turanose & - & + & - & - & - & - & - & + & - & - & + \\
\hline$\alpha$-Methyl-D-glucoside & - & - & - & - & - & - & - & + & - & - & - \\
\hline Glycerol & - & - & - & - & - & - & - & + & - & - & - \\
\hline \multicolumn{12}{|l|}{ Activity of:† } \\
\hline Esterase (C-4) & + & + & + & + & - & + & + & + & + & + & + \\
\hline Esterase lipase (C-8) & - & + & + & + & + & + & + & + & + & + & + \\
\hline Lipase (C-4) & - & + & + & - & - & - & - & - & + & + & - \\
\hline Valine arylamidase & + & + & + & + & + & + & + & + & + & - & + \\
\hline Cystine arylamidase & - & + & + & - & - & - & - & + & + & + & + \\
\hline Trypsin & - & - & + & + & - & - & + & - & + & + & + \\
\hline Chymotrypsin & - & + & + & + & - & + & - & - & + & + & - \\
\hline$\alpha$-Galactosidase & - & - & - & - & - & - & - & - & - & - & + \\
\hline$\beta$-Galactosidase & - & + & + & - & - & - & - & + & + & + & + \\
\hline$\beta$-Glucuronidase & - & - & - & - & - & - & - & - & + & + & + \\
\hline$\alpha$-Glucosidase & - & + & + & + & + & + & + & + & + & + & + \\
\hline$\beta$-Glucosidase & - & + & + & + & + & + & - & + & + & + & + \\
\hline$N$-Acetyl- $\beta$-glucosaminidase & - & - & - & - & - & - & - & + & - & - & - \\
\hline
\end{tabular}

* Assimilation tests for which all strains gave negative results were: D-arabinose, L-arabitol, L-xylose, L-sorbose, D-lyxose, D-tagatose, D-arabitol, $\beta$-methylxylose, ribose, inositol, inulin, erythritol, adonitol, dulcitol, xylitol, mannitol, sorbitol, glycogen, $\alpha$-methyl-Dmannose, gluconate, 2-keto-gluconate and 5-keto-gluconate.

$\dagger$ Enzyme activity tests for which all strains gave positive results were: alkaline phosphatase, acid phosphatase, leucine arylamidase and naphthol-AS-BI-phosphohydrase; tests for which all strains gave negative results were: $\alpha$-mannosidase and $\alpha$-fucosidase.

to adaptation to nonylphenol. It is known that highly adapted strains must be subcultured several times in a full medium before they again show their typical physiological behaviour. Thus we subcultured S-3 $3^{\mathrm{T}}$ repeatedly (five times) with nutrient broth and nutrient agar before the assimilation pattern tests. However, S$3^{\mathrm{T}}$ again did not show any positive results in the tests, while NP-degrading activity was stable. 
Table 3 Levels of DNA-DNA reassociation of S-3 $3^{\top}$ with other Sphingomonas strains

\begin{tabular}{|c|c|c|c|c|c|c|c|c|c|c|c|c|}
\hline \multirow[t]{2}{*}{ Strain } & \multirow{2}{*}{$\begin{array}{c}\mathbf{G}+\mathbf{C} \\
\text { content } \\
(\mathrm{mol} \%)^{*}\end{array}$} & \multicolumn{11}{|c|}{ Reassociation (\%) with labelled DNA from: } \\
\hline & & $\mathrm{S}-\mathbf{3}^{\mathrm{T}}$ & yan & pau & chl & $h r b$ & HV3 & RA2 & sng & cps & nat & asc \\
\hline $\mathrm{S}-3^{\mathrm{T}}$ & 63 & 100 & 17 & 10 & 20 & 16 & 16 & 18 & 5 & 3 & 1 & 0 \\
\hline S. yanoikuyae (yan) & $62^{a}$ & 19 & 100 & 8 & 19 & 17 & 15 & 16 & 6 & 5 & 4 & 3 \\
\hline S. paucimobilis (pau) & $64^{a}$ & 13 & 10 & 100 & 9 & 7 & 5 & 8 & 40 & 6 & 5 & 7 \\
\hline S. chlorophenolica $(\mathrm{chl})$ & 65 & 27 & 23 & 11 & 100 & 23 & 31 & 66 & 9 & 6 & 4 & 2 \\
\hline S. herbicidovorans (hrb) & NA & 16 & 15 & 7 & 17 & 100 & 18 & 15 & 5 & 5 & 4 & 2 \\
\hline Sphingomonas sp. HV3 (HV3) & $64^{b}$ & 18 & 19 & 7 & 31 & 23 & 100 & 35 & 7 & 5 & 5 & 4 \\
\hline Sphingomonas sp. RA2 (RA2) & NA & 23 & 21 & 9 & 69 & 23 & 36 & 100 & 8 & 6 & 6 & 5 \\
\hline S. sanguinis (sng) & $62^{a}$ & 9 & 9 & 42 & 9 & 6 & 5 & 5 & 100 & 4 & 3 & 5 \\
\hline S. capsulata (cps) & $64^{a}$ & 9 & 9 & 6 & 8 & 6 & 5 & 4 & 4 & 100 & 3 & 0 \\
\hline S. natatoria (nat) & NA & 5 & 7 & 6 & 6 & 6 & 6 & 6 & 5 & 5 & 100 & 5 \\
\hline S. asaccharolytica (asc) & $65^{c}$ & 3 & 4 & 7 & 4 & 3 & 3 & 3 & 6 & 1 & 3 & 100 \\
\hline
\end{tabular}

NA, Not available.

* Data from: a, Takeuchi et al. (1993); b, Yrjala et al. (1998); c, Takeuchi et al. (1995).

On the other hand, we found that $\mathrm{S}-3^{\mathrm{T}}$ could grow aerobically with YNB containing $0 \cdot 1 \%$ tryptone or proline as sole carbon source. Therefore, it is less likely that the negative results of $\mathrm{S}-3^{\mathrm{T}}$ are due to adaptation to NP. We think that $\mathrm{S}-3^{\mathrm{T}}$ can utilize some uncommon carbon sources, including at least NP and proline, but cannot assimilate the carbohydrates tested in our study.

Tests of oxidase and catalase activities were found to be positive, and several other enzyme activities were also detected. However, tests of the carbohydratedegrading enzymes of $\mathrm{S}-3^{\mathrm{T}}$ were all negative, which is consistent with its carbohydrate assimilation pattern (Table 2).

\section{DNA analysis}

The $\mathrm{G}+\mathrm{C}$ content of the genomic DNA of $\mathrm{S}-3^{\mathrm{T}}$ was determined as $63 \mathrm{~mol} \%$ (Table 3). This value falls within the range observed for other members of the genus Sphingomonas, namely $61.6-67.8 \mathrm{~mol} \%$ (Takeuchi et al., 1993; Yabuuchi et al., 1990).

From the analysis of $16 \mathrm{~S}$ rDNA sequences, S- $3^{\mathrm{T}}$ showed similarity to several Sphingomonas spp., including Sphingomonas yanoikuyae, Sphingomonas chlorophenolica, Sphingomonas paucimobilis, Sphingomonas herbicidovorans, Sphingomonas sp. HV3 and Sphingomonas sp. RA2 (Fig. 2). We have confirmed that other clustering methods (maximum-likelihood methods) using the PHYLIP program (Felsenstein, 1995) lead to the same grouping.

However, the sequence similarity of the 16S rDNA of $\mathrm{S}-3^{\mathrm{T}}$ with that of these species was $96 \%$ at most, implying that $\mathrm{S}-3^{\mathrm{T}}$ should be regarded as distinctive. Therefore, DNA-DNA hybridization experiments were carried out to obtain more conclusive infor-

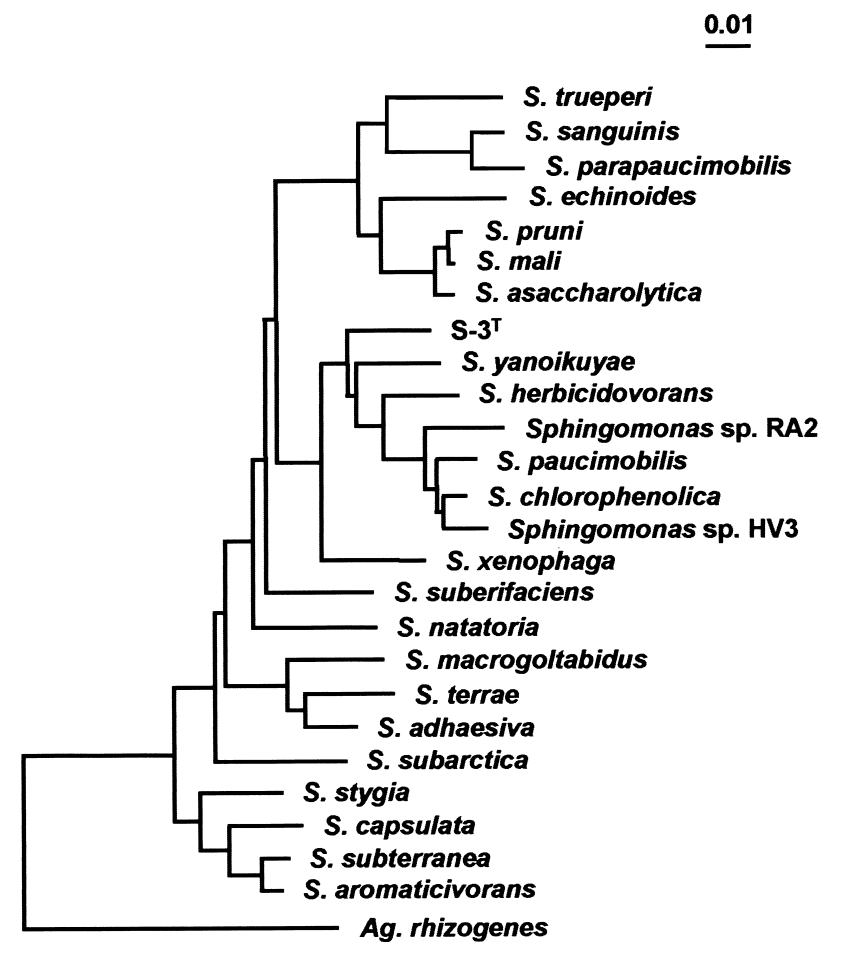

Fig. 2. Phylogenetic tree constructed by the neighbour-joining method based on $16 \mathrm{~S}$ rDNA sequences of S-3 $3^{T}$ and related bacteria. Scale bar represents an evolutionary distance $\left(K_{\text {nuc }}\right)$ of 0.01 .

mation on the relationship between $\mathrm{S}-3^{\mathrm{T}}$ and known Sphingomonas species. Six species forming a cluster with $\mathrm{S}-3^{\mathrm{T}}$, and four random species forming a distinct grouping in the phylogenetic tree of 16S rDNA (Fig. 2) were studied. Table 3 shows levels of DNA-DNA reassociation values among these species, indicating 
Table 4 Whole-cell fatty acid profile of S-3 $3^{\top}$

S. chlorophenolica $(c h l)$ was used as control.

\begin{tabular}{|llc|}
\hline \multirow{2}{*}{ Fatty acid } & \multicolumn{2}{c|}{ Percentage in: } \\
\cline { 2 - 3 } & $\mathbf{S - 3}^{\mathbf{T}}$ & chl \\
\hline Saturated fatty acids & & \\
$14: 0$ & $0 \cdot 12$ & $0 \cdot 11$ \\
$14: 0$ 2-OH & $2 \cdot 8$ & $2 \cdot 7$ \\
$16: 0$ & $7 \cdot 2$ & $8 \cdot 7$ \\
$16: 0$ 2-OH & $0 \cdot 20$ & $0 \cdot 38$ \\
$17: 0$ & $0 \cdot 33$ & $0 \cdot 22$ \\
$18: 0$ & $0 \cdot 66$ & $0 \cdot 86$ \\
$19: 0$ & $1 \cdot 7$ & $0 \cdot 21$ \\
$22: 0$ & tr & $\operatorname{tr}$ \\
Unsaturated fatty acids & & \\
$16: 1(9)$ & $3 \cdot 3$ & $8 \cdot 8$ \\
$16: 1(7)$ & $0 \cdot 73$ & $1 \cdot 6$ \\
$16: 1$ 2-OH & $1 \cdot 3$ & $1 \cdot 3$ \\
$18: 1(11)$ & $1 \cdot 3$ & ND \\
Summed feature* & 80 & 75 \\
3-OH fatty acids & ND & ND \\
\hline
\end{tabular}

ND, Not detected.

tr, Trace (less than $0 \cdot 1 \%$ ).

* Summed feature consists mainly of 18:1 fatty acid and could not be separated completely under our experimental conditions.

relatively low levels of hybridization (maximum $27 \%$ ). It has been recommended that phylogenetically defined species should consist of strains that exhibit approximately $70 \%$ or higher DNA-DNA hybridization values (Wayne et al., 1987). Therefore, our findings strongly suggest that $\mathrm{S}-3^{\mathrm{T}}$ is distinct from other known Sphingomonas species.

\section{Cellular fatty acid composition and polar lipid pattern of S-3 ${ }^{\mathbf{T}}$}

The whole-cell fatty acid profile of $\mathrm{S}-3^{\mathrm{T}}$ is shown in Table 4. The major non-polar fatty acids that were found were 18:1 and 16:0, while 2-hydroxymyristic acid $(14: 02-\mathrm{OH})$ was present as the dominant hydroxylated fatty acid. However, 3-hydroxylated fatty acids were not found. These results are consistent with the description of the genus Sphingomonas (Yabuuchi et al., 1990; Takeuchi et al., 1993, 1994; Kampfer et al., 1997; Stolz et al., 2000).

The total polar lipid profile was examined by twodimensional TLC (data not shown). Several major spots of phospholipids and minor spots of unidentified lipids emerged on the TLC plate. Furthermore, staining of the plate with $\alpha$-naphthol/sulphuric acid, periodate-Schiff reagent, Zinzadze (Dittmer) reagent and ninhydrin revealed a spot of sphingoglycolipid, the unique lipid found in the genus Sphingomonas (Kampfer et al., 1997), suggesting that $\mathrm{S}-3^{\mathrm{T}}$ is a Sphingomonas species.

\section{Isoprenoid quinone analysis}

The isoprenoid quinone composition of $\mathrm{S}-3^{\mathrm{T}}$ was determined. It contained ubiquinone, which consisted mainly of Q-10. The presence of ubiquinone Q-10 as the predominant isoprenoid quinone is typical for members of the $\alpha$-subclass of the Proteobacteria, which includes the genus Sphingomonas (Yabuuchi et al., 1990; Yrjala et al., 1998; Stolz et al., 2000).

\section{Conclusions}

Recently, study of the genus Sphingomonas has become one of the most competitive research fields since various xenobiotic-degrading species have been reported. For example, S. paucimobilis and S. yanoikuyae are known to assimilate naphthalene and biphenyl (Gibson et al., 1973; Furukawa et al., 1983; Yabuuchi et al., 1990; Kuhm et al., 1991; Khan et al., 1996). Sphingomonas chlorophenolica, Sphingomonas subarctica and Sphingomonas sp. RA2 are able to assimilate chlorinated phenols (Radehaus \& Schmidt, 1992; Karlson et al., 1995; Nohynek et al., 1996; McCarthy et al., 1997; Ohtsubo et al., 1999). S. herbicidovorans has been found to utilize herbicides as carbon sources (Horvath et al., 1990; Zipper et al., 1996, 1998). Sphingomonas xenophaga and Sphingomonas sp. HV3 have been reported to assimilate several aromatic and chloroaromatic compounds (Kilpi et al., 1980; Yrjala et al., 1998; Stolz et al., 2000).

The 16S rDNA sequence (Fig. 2), the $\mathrm{G}+\mathrm{C}$ content of the genomic DNA (Table 3), the isoprenoid quinone composition, the whole-cell fatty acid profile (Table 4) and the presence of sphingoglycolipid suggested that $\mathrm{S}-3^{\mathrm{T}}$ belongs to the genus Sphingomonas.

However, the level of similarity of the 16S rDNA between $\mathrm{S}-3^{\mathrm{T}}$ and other known Sphingomonas spp. suggested that $\mathrm{S}-3^{\mathrm{T}}$ is a novel species within this genus. Comparison of the phenotypic characteristics of $\mathrm{S}-3^{\mathrm{T}}$ (Table 2) with those of other members of Sphingomonas (Yabuuchi et al., 1990; Takeuchi et al., 1995; Balkwill et al., 1997; Kampfer et al., 1997; Stolz et al., 2000) also demonstrated significant differences, supporting our conclusion that $\mathrm{S}-3^{\mathrm{T}}$ is distinct from known members of the genus. Finally, the DNA-DNA hybridization experiments (Table 3) clearly showed that $\mathrm{S}-3^{\mathrm{T}}$ is a novel species of the genus Sphingomonas.

Based on the phenotypic, genotypic and phylogenetic data obtained in our study, it was concluded that the strain S-3 $3^{\mathrm{T}}$ should be classified as a new species of the genus Sphingomonas. We therefore propose the name Sphingomonas cloacae for this novel organism.

\section{Description of Sphingomonas cloacae sp. nov.}

Sphingomonas (clo.a'cae. L. n. cloaca sewer, the source of the organism).

Gram-negative, aerobic and rod-shaped bacterium (2.0-3.1 $\mu \mathrm{m}$ long, $1 \cdot 1-1 \cdot 4 \mu \mathrm{m}$ diameter). Colonies are circular, entire, convex, dry, opaque and creamy white. 
Cells are able to grow in nutrient broth at $25^{\circ} \mathrm{C}$, but not at 4 or $42{ }^{\circ} \mathrm{C}$. NP, an endocrine disrupter chemical, and proline are assimilated, but the carbohydrates tested in our study, including glucose, galactose, xylose, arabinose, trehalose, fructose, sucrose and maltose, are not. Oxidase, catalase, alkaline phosphatase, acid phosphatase, leucine arylamidase, valine arylamidase, naphthol-AS-BI-phosphohydrase and esterase activities are positive. The $\mathrm{G}+\mathrm{C}$ content of the DNA is $63 \mathrm{~mol} \%$. The major non-polar fatty acids are 18:1 and 16:0, and the major 2-hydroxy fatty acid is 14:0 2-OH. 3-Hydroxy fatty acids were not detected. Sphingoglycolipid is present. The major isoprenoid quinone is ubiquinone Q-10. Isolated from wastewater of a sewage-treatment plant in Tokyo. The type strain is strain S-3 $3^{\mathrm{T}}\left(=\mathrm{JCM} 10874^{\mathrm{T}}=\mathrm{IAM}\right.$ $\left.14885^{\mathrm{T}}\right)$. The $16 \mathrm{~S}$ rDNA sequence has been deposited at the DDJB database under accession number AB040739.

\section{ACKNOWLEDGEMENTS}

This study was supported by grant-in-aid from the Japan Society for the Promotion of Science, Ministry of Education, Japan, to K.F. We would also like to thank Mr Kenji Ishihara for his technical assistance.

\section{REFERENCES}

Ahel, M. \& Giger, W. (1985). Determination of alkylphenols and alkylphenol mono- and diethoxylates in environmental samples by high-performance liquid chromatography. Anal Chem 57, 1577-1583.

Ahel, M., McEvoy, J. \& Giger, W. (1993). Bioaccumulation of the lipophilic metabolites of nonionic surfactants in freshwater organisms. Environ Pollut 79, 243-248.

Altschul, S. F., Gish, W., Miller, W., Myers, E. W. \& Lipman, D. J. (1990). Basic logical alignment search tool. J Mol Biol 215, 403-410.

American Oil Chemists' Society (1990). Official Methods and Recommended Practices, 4th edn. Chicago: American Oil Chemists' Society

Ashfield, L. A., Pottinger, T. G. \& Sumpter, J. P. (1998). Exposure of female juvenile rainbow trout to alkylphenolic compounds results in modification to growth and ovosomatic index. Environ Toxicol Chem 17, 679-686.

Balkwill, D. L., Drake, G. R., Reeves, R. H. \& 7 other authors (1997). Taxonomic study of aromatic-degrading bacteria from deep-terrestrial-subsurface sediments and description of Sphingomonas aromaticivorans sp. nov., Sphingomonas subterranea sp nov., and Sphingomonas stygia sp. nov. Int J Syst Bacteriol 47, 191-201

Bligh, E. J. \& Dyer, W. J. (1959). A rapid method of total lipid extraction and purification. Can J Biochem Physiol 37, 911-917.

Brunner, P. H., Capli, S., Marcomini, A. \& Giger, W. (1988). Occurrence and behavior of linear alkylbenzene sulphonates, nonylphenol, nonylphenol mono- and nonylphenol diethoxylates in sewage and sewage sludge treatment. Water Res 22, 1465-1472.

Coldham, N. G., Sivapathasundaram, S., Dave, M., Ashfield, L. A., Pottinger, T. G., Goodall, C. \& Sauer, M. J. (1998). Biotransformation, tissue distribution, and persistence of 4-nonylphenol residues in juvenile rainbow trout (Oncorhynchus mykiss). Drug Metab Dispos 26, 347-354.

Ekelund, R., Bergman, A., Granmo, A. \& Berggren, M. (1990). Bioaccumulation of 4-nonylphenol in marine animals. A reevaluation. Environ Pollut 64, 107-120.

Ezaki, T., Hashimoto, Y. \& Yabuuchi, Y. (1989). Fluorometric deoxyribonucleic acid-deoxyribonucleic acid hybridization in microdilution wells as an alternative to membrane filter hybridization in which radioisotopes are used to determine genetic relatedness among bacterial strains. Int J Syst Bacteriol 39, 224-229.

Felsenstein, J. (1995). PHYLIP - phylogeny inference package (version 3.57c). Seattle, WA: University of Washington.

Fujii, K., Urano, N., Kimura, S., Nomura, Y. \& Karube, I. (2000). Microbial degradation of nonylphenol in some aquatic environments. Fish Sci 66, 44-48.

Furukawa, K., Simon, J. R. \& Chakrabarty, A. M. (1983). Common induction and regulation of biphenyl, xylene/toluene, and salicylate catabolism in Pseudomonas paucimobilis. $J$ Bacteriol 154, 1356-1362.

Gibson, D. T., Roberts, R. L., Wells, M. C. \& Kobal, V. M. (1973). Oxidation of biphenyl by a Beijerinckia species. Biochem Biophys Res Commun 50, 211-219.

Giger, W., Brunner, P. H. \& Schaffner, W. (1984). 4-Nonylphenol in sewage sludge: accumulation of toxic metabolites from nonionic surfactants. Science 225, 623-625.

Granmo, A., Ekelund, R., Magnusson, K. \& Berggren, M. (1989). Lethal and sublethal toxicity of 4-nonylphenol to the common mussel (Mytilus edulis L.) Environ Pollut 59, 115-127.

Gray, M. A. \& Metcalfe, C. D. (1997). Induction of testis-ova in Japanese Medaka (Orizias Latipes) exposed to $p$-nonylphenol. Environ Toxicol Chem 16, 1082-1086.

Horvath, M., Ditzelmuller, G., Loidl, M. \& Streichsbier, F. (1990). Isolation and characterization of a 2-(2,4-dichlorophenoxy) propionic acid-degrading soil bacterium. Appl Microbiol Biotechnol 33, 213-216.

Isobe, T. \& Takada, H. (1998). Behavior and effect of nonylphenol in aquatic environment. Mizukankyougakkaishi 21, 203-208 (in Japanese).

Jobling, S. \& Sumpter, J. P. (1993). Detergent components in sewage effluent are weakly estrogenic to fish: an in vitro study using rainbow trout (Oncorhynchus mykiss) hepatocytes. Aquat Toxicol 27, 361-372.

Kampfer, P., Denner, E. B. M., Meyer, S., Moore, E. R. B. \& Busse, H.-J. (1997). Classification of "Pseudomonas azotocolligans" Anderson 1955, 132, in the genus Sphingomonas as Sphingomonas trueperi $\mathrm{sp}$. nov. Int $J$ Syst Bacteriol 47, 577-583.

Karlson, U., Rojo, F., van Elsas, J. D. \& Moore, E. (1995). Genetic and serological evidence for the recognition of four pentachlorophenol-degrading bacterial strains as a species of the genus Sphingomonas. Syst Appl Microbiol 18, 539-548.

Khan, A. A., Wang, R. F., Cao, W. W., Franklin, W. \& Cerniglia, C. E. (1996). Reclassification of polycyclic aromatic hydrocarbon-metabolizing bacterium, Beijerinckia sp. strain B1, as Sphingomnas yanoikuyae by fatty acid analysis, protein pattern analysis, DNA-DNA hybridization, and 16S ribosomal DNA sequencing. Int J Syst Bacteriol 46, 466-469.

Kilpi, S., Backstrom, V. \& Korhola, M. (1980). Degradation of 2methyl-4-chlorophenoxyacetic acid (MCPA), 2,4-dichlorophenoxyacetic acid (2,4-D), benzoic acid and salicylic acid by Pseudomonas sp. HV3. FEMS Microbiol Lett 8, 177-182.

Kimura, M. (1980). A simple method for estimating evolutionary 
rates of base substitutions through comparative studies of nucleotide sequences. $J$ Mol Biol 16, 111-120.

Kojima, S. \& Watanabe, M. (1998). Distribution of alkylphenol polyethoxylate (APE) and their metabolites in the aquatic environment in Nagoya city. Mizukankyougakkaishi 21, 302-309 (in Japanese).

Kuhm, A. E., Stolz, A. \& Knackmuss, H. J. (1991). Metabolism of naphthalene by the biphenyl-degrading bacterium Pseudomonas paucimobilis Q1. Biodegradation 2, 115-120.

McCarthy, D. L., Claude, A. A. \& Copley, S. D. (1997). In vivo levels of chlorinated hydroquinones in a pentachlorophenoldegrading bacterium. Appl Environ Microbiol 63, 1883-1888.

Marcomini, A., Pavoni, B., Sfriso, A. \& Orio, A. A. (1990). Persistent metabolites of alkylphenol polyethoxylates in the marine environment. Mar Chem 29, 307-323.

Nohynek, L. J., Nurmiaho-Lassila, E. L., Suhonen, E. L., Busse, H.-J., Mohammadi, M., Hantula, J., Rainey, F. \& SalkinojaSalonen, M. S. (1996). Description of chlorophenol-degrading Pseudomonas sp. strains KF1T, KF3, and NKF1 as a new species of the genus Sphingomonas, Sphingomonas subarctica sp. nov. Int J Syst Bacteriol 46, 1042-1055.

Ohtsubo, Y., Miyauchi, K., Kanda, K., Hatta, T., Kiyohara, H., Senda, T., Nagata, Y., Mitsui, Y. \& Takagi, M. (1999). PcpA, which is involved in the degradation of pentachlorophenol in Sphingomonas chlorophenolica ATCC39723, is a novel type of ringcleavage dioxygenase. FEBS Lett 459, 395-398.

Radehaus, P. M. \& Schmidt, S. K. (1992). Characterization of a novel Pseudomonas sp. that mineralizes high concentrations of pentachlorophenol. Appl Environ Microbiol 58, 2879-2885.

Ren, L., Marquardt, M. A. \& Lech, J. J. (1997). Estrogenic effects of nonylphenol on $\mathrm{pS} 2$, ER and MUC1 gene expression in human breast cancer cells MCF-7. Chem-Biol Interact 104, 55-64.

Rudel, R. A., Melly, S. J., Geno, P. W., Sun, G. \& Brody, J. G. (1996). Identification of alkylphenols and other estrogenic compounds in wastewater, septage, and groundwater on cape Cod, Massachusetts. Environ Sci Technol 32, 861-869.

Saitou, N. \& Nei, M. (1987). The neighbor-joining method: a new method for reconstructing phylogenic trees. Mol Biol Evol 4, 406-425.

Sambrook, J., Fritsch, E. F. \& Maniatis, T. (1989). Molecular Cloning: a Laboratory Manual, 2nd edn. Cold Spring Harbor, NY : Cold Spring Harbor Laboratory.

Satomi, M., Kimura, B., Mizoi, M., Satou, T. \& Fujii, T. (1997). Tetragenococcus muriaticus sp. nov., a new moderately halophilic lactic acid bacterium isolated from fermented squid liver sauce. Int J Syst Bacteriol 47, 832-836.

Shurin, J. B. \& Dodson, S. I. (1997). Sublethal toxic effects of cyanobacteria and nonylphenol on environmental sex determination and development in Daphnia. Environ Toxicol Chem 16, 1269-1276.

Sonnenschein, C. \& Soto, A. M. (1998). An updated review of environmental estrogen and androgen mimics and antagonist. $J$ Steroid Biochem Mol Biol 65, 143-150.

Soto, A. M., Justica, H., Wray, J. W. \& Sonnenschein, C. (1991). Para-nonylphenol: an estrogenic xenobiotic released from "modified" polystyrene. Environ Health Perspect 92, 167-173.

Stolz, A., Schmidt-Maag, C., Denner, E. B. M., Busse, H.-J., Egli, T. \& Kampfer, P. (2000). Description of Sphingomonas xenophaga sp. nov. for strains BN6T and N,N which degrade xenobiotic aromatic compounds. Int J Syst Evol Microbiol 50, 35-41.

Suzuki, T. \& Yamasato, K. (1994). Phylogeny of spore-forming lactic acid bacteria based on $16 \mathrm{~S}$ rRNA gene sequences. FEMS Microbiol Lett 115, 13-18.

Takeuchi, M., Kawai, F., Shimada, Y. \& Yokota, A. (1993). Taxonomic study of polyethylene glycol-utilizing bacteria: emended description of the genus Sphingomonas and new description of Sphingomonas macrogoltabidus sp. nov., Sphingomonas sanguis sp. nov., and Sphingomonas terrae sp. nov. Syst Appl Bacteriol 16, 2227-2238.

Takeuchi, M., Sawada, H., Oyaizu, H. \& Yokota, A. (1994). Phylogenetic evidence for Sphingomonas and Rhizomonas as nonphotosynthetic members of the alpha-4 subclass of the Proteobacteria. Int J Syst Bacteriol 44, 308-314.

Takeuchi, M., Sakane, T., Yanagi, M., Yamasato, K., Hamana, K. \& Yokota, A. (1995). Taxonomic study of bacteria isolated from plants: proposal of Sphingomonas rosa sp. nov., Sphingomonas pruni sp. nov., Sphingomonas asaccharolytica sp. nov., and Sphingomonas mali sp. nov. Int J Syst Bacteriol 45, 334-341.

Tamaoka, J. \& Komagata, K. (1984). Determination of DNA base composition by reversed-phase high performance liquid chromatography. FEMS Microbiol Lett 25, 125-128.

Thompson, J. D., Higgins, D. G. \& Gibson, T. J. (1994). CLUSTAL $\mathrm{W}$ : improving the sensitivity of progressive multiple sequence alignment through sequence weighting, position-specific gap penalties and weight matrix choice. Nucleic Acids Res 22, 4673-4680.

Wayne, L. G., Brenner, D. J., Colwell, R. R. \& 9 other authors (1987). International Committee on Systematic Bacteriology. Report of the ad hoc committee on reconciliation of approaches to bacterial systematics. Int J Syst Bacteriol 37, 463-464.

Weisburg, W. G., Barns, S. M., Pelletier, D. A. \& Lane, D. J. (1991). $16 \mathrm{~S}$ ribosomal DNA amplification for phylogenetic study. $J$ Bacteriol 173, 697-703.

Yabuuchi, E., Yano, I., Oyaizu, H., Hashimoto, Y., Ezaki, T. \& Yamamoto, H. (1990). Proposals of Sphingomonas paucimobilis gen. nov. and comb. nov., Sphingomonas parapaucimobilis sp. nov., Sphingomonas yanoikuyae sp. nov., Sphingomonas adhaesiva sp. nov., Sphingomonas capsulata comb. nov., and two genospecies of the genus Sphingomonas. Microbiol Immunol 34, 99-119.

Yamada, Y. \& Kuraishi, I. (1982). Ubiquinone and menaquinone. In Biseibutsu no Kagakubunrui Jikkenhou, pp. 143-155. Edited by K. Komagata. Tokyo: Gakkai Shuppan Center (in Japanese).

Yrjala, K., Suomalainen, S., Suhonen, E. L., Kilpi, S., Paulin, L. \& Romantschuk, M. (1998). Characterization and reclassification of an aromatic- and chloroaromatic-degrading Pseudomonas sp., strain HV3, as Sphingomonas sp. HV3. Int J Syst Bacteriol 48, 1057-1062.

Zipper, C., Nickel, K., Angst, W. \& Kohler, H. P. E. (1996). Complete microbial degradation of both enantiomers of chiral herbicide mecoprop [(RS)-2-(4-chloro-2-methylphenoxy)propionic acid] in an enantioselective manner by Sphingomonas herbicidovorans sp. nov. Appl Environ Microbiol 62, 4318-4322.

Zipper, C., Bunk, M., Zehnder, A. J. B. \& Kohler, H. P. E. (1998). Enantioselective uptake and degradation of the chiral herbicide dichlorprop [(RS)-2-(2,4-dichlorophenoxy)propanoic acid] by Sphingomonas herbicidovorans MH. J Bacteriol 180, 3368-3374. 